\title{
SELECTION OF MICROORGANISMS PRODUCER OF LIPASE FOR FAT REMOVAL FROM BIODIESEL PURIFICATION WATER
}

\author{
DAYANE C. DA ROCHA ${ }^{1}$, BENEDITO M. GOMES ${ }^{2}$, SIMONE D.GOMES ${ }^{3}$, \\ LUCIANE SENE ${ }^{4}$, DILCEMARA C. ZENATTI ${ }^{5}$
}

\begin{abstract}
The objective this study has been the selection of lipase productor microorganism, for removal of oils and grease, in the pre-treatment of biodiesel wastewater washing. For this, analyses of the physicist-chemistries characteristics had been made with the wastewater of the biodiesel washing, and then it had been isolated and chosen, by means of determinations of the lipase activity. Following, it was made a test of fat biodegradation, in the conditions: $\mathrm{pH}$ (5.95), temperature $\left(35^{\circ} \mathrm{C}\right)$, rotation $(180 \mathrm{rpm})$ and ammonium sulfate as nitrogen source $\left(3 \mathrm{~g} \mathrm{~L}^{-1}\right)$ and establishing as variable the two microorganism preselected and the time $(24 ; 48 ; 72 ; 96$ and $120 \mathrm{~h})$. The biodiesel purification wastewater had presented high potential of environmental impact, presenting a concentration of O\&G of $6.76 \mathrm{~g} \mathrm{~L}^{-1}$. From the six isolated microbiological cultures, two microorganisms ( $\mathrm{A}$ and $\mathrm{B}$ ) had been selected, with enzymatic index of 0.56 and 0.57 , respectively. The treatment of the wastewater using the isolated microorganism (Klebsiella oxytoca) had $80 \%$ of the fatty removal in $48 \mathrm{~h}$.
\end{abstract}

KEYWORDS: enzymatic degradation, fatty effluent, lipolytical activity.

\section{SELEÇÃO DE MICRORGANISMOS PRODUTORES DE LIPASE PARA REMOÇÃO DE GORDURA DE ÁGUA DE PURIFICAÇÃO DO BIODIESEL}

RESUMO: Este trabalho teve por objetivo selecionar cepas de microrganismos com alto potencial de produção de lipase, a fim de remover óleos e graxas, no pré-tratamento da água residuária de purificação do biodiesel. Para tanto, foram feitas análises das características físico-químicas do efluente, e a partir desse resíduo foram isolados e selecionados microrganismos com potencial de produção de lipase. Em seguida, foi feito um ensaio de biodegradação de gordura, nas condições: pH $(5,95)$, temperatura $\left(35^{\circ} \mathrm{C}\right)$, rotação $(180 \mathrm{rpm})$ e sulfato de amônio como fonte de nitrogênio $\left(3 \mathrm{~g} \mathrm{~L}^{-1}\right)$, e tendo como variáveis os microrganismos pré-selecionados e o tempo $(24 ; 48 ; 72 ; 96 \mathrm{e}$ 120 h). A água residuária de purificação do biodiesel apresentou uma concentração de $O \& G$ de $6,76 \mathrm{~g} \mathrm{~L}^{-1}$. Das seis culturas microbianas isoladas do tanque de decantação deste efluente, dois microrganismos (A e B) foram selecionados, com índice enzimático de 0,56 e 0,57, respectivamente. $\mathrm{O}$ tratamento da água residuária, utilizando o microrganismo isolado Klebsilla oxytoca, obteve uma remoção de O\&G de $80 \%$ em 48 h.

PALAVRAS-CHAVE: biodegradação enzimática, efluentes gordurosos, atividade lipolítica.

\section{INTRODUCTION}

The high demand for energy in the industrialized world and in the domestic sector as well as the pollution problems caused due to the wide use of these fuels, have stimulated recent interests in finding alternative sources for petroleum-based fuels (GERIS et al., 2007).

\footnotetext{
${ }^{1}$ Mestre em Engenharia Agrícola, Universidade Estadual do Oeste do Paraná (UNIOESTE). daycris_rocha@yahoo.com.br

${ }^{2}$ Prof. Associado, Centro de Ciências Exatas e Tecnológicas, Universidade Estadual do Oeste do Paraná (UNIOESTE), benedito.gomes@unioeste.br

${ }^{3}$ Profa. Associada, Centro de Ciências Exatas e Tecnológicas, Universidade Estadual do Oeste do Paraná (UNIOESTE), simone.gomes@unioeste.br

${ }^{4}$ Profa. Doutora, Centro de Ciências Médicas e Farmacêuticas, Universidade Estadual do Oeste do Paraná (UNIOESTE), luciane.sene@unioeste.br

${ }^{5}$ Profa. Assistente, Curso Superior de Tecnologia em Biocombustíveis, Universidade Federal do Paraná (UFPR), dil.zenatti@ufpr.br Recebido pelo Conselho Editorial em: 4-11-2010

Aprovado pelo Conselho Editorial em: 15-10-2012
} 
Therefore, vegetable oils and animal fat have been studied as potential renewable source for biofuel production. The transesterification process is the most frequently used for production of biodiesel. This process consists in the chemical reaction of vegetable oils or animal fat with alcohol, ethanol or methanol, in the presence of a basic catalyst, acidic or enzymatic (RAMOS et al., 2003). After this production process, during the stage of biodiesel purification, there is the formation of wastewater with high content of oils and greases, which have the potential to contaminate water bodies, damaging the balance necessary to maintain aquatic ecosystems.

The biodiesel wastewater purification features several parameters, such as oil and grease, DQO, DBO, color, turbidity, $\mathrm{pH}$, not complying with resolution of CONAMA $\mathrm{n}^{\mathrm{o}}$ 430/2011 laying down detailed conditions for the discharge of effluents into water bodies observing a need of treatment of these effluents (DRANKA et al., 2008).

In order to try solving these problems, alternative methods have been used in order to reduce the concentration of lipids contained in effluents with high organic load. The enzymatic treatment of effluents is interesting because it helps to improve the efficiency of conventional treatments (VALLADÃO et al., 2007).

The use of enzymes in effluent treatment offers several potential advantages, such as simplicity and ease in process control; there is no need of acclimatization of biomass; there is no effects of shock by load of pollutants; may be applied in processes with high or low concentration of pollutants and operate in wide ranges of $\mathrm{pH}$, temperature and salinity. Among different possibilities, the enzymes may be used in the treatment of effluents generated in the oil, textile, paper and cellulose derivatives, foods in general, among other (MENDES et al., 2005).

One proposal is to use enzymatic hydrolysis by lipases for removing oil and grease from these effluents, either by the use of microorganisms that produce lipase, or by the use of enzymes (isolated or not) (DURLI, 2007).

These enzymes feature particular importance, by the fact that they hydrolyze specifically fats and oils, which may be of great interest for the treatment of effluents with high fat content (MENDES et al., 2005). Lipase (triacylglycerol hydrolases, EC 3.1.1.3) is responsible for the catalysis of reactions involving hydrolysis and ester synthesis from glycerol and long-chain fatty acids, causing them to be considered as an important group of biocatalysts, occurring its performance in oil-water interface (CASTRO \& ANDERSON, 1995).

The application of a pre-treatment to hydrolyze and dissolve fats can improve the biological degradation of effluents with a high content of oils and greases, accelerating the process and reducing the time of it. (ALESSI, 2005). Thus, this study aimed to select strains of microorganisms with high potential of lipase production, in order to remove oils and greases, in the pre-treatment of the wastewater of biodiesel purification.

\section{MATERIAL AND METHODS}

The experiment was conducted in the "Laboratório de Saneamento Ambiental e Enzimologia e Tecnologia das Fermentações da Universidade Estadual do Oeste do Paraná - UNIOESTE" (Laboratory of Environmental Sanitation and Enzymology, and Fermentation Technology of the State University of Western Paraná - UNIOESTE) - campus Cascavel, state of Paraná, Brazil. It was used the wastewater of biodiesel purification from an industry that produces biofuel in the northern Paraná, in which the process occurs by transesterification between soybean oil and methanol, with sodium methylate as catalyst.

The effluent was collected in the output, after the purification process, end of the box of fat retention, in sterilized glass vials, packed in thermic box for transportation to the laboratory.

For the characterization of this residue, parameters and methodologies (described in Table 1) were considered. 
TABLE 1. Parameter evaluated for wastewater characterization.

\begin{tabular}{|c|c|c|c|c|}
\hline Parameter & Unity & Method & $\begin{array}{c}\text { Protocols APHA, } \\
\text { AWWA, WEF (2005) }\end{array}$ & Different Method \\
\hline ST & $\mathrm{mg} \mathrm{L}^{-1}$ & gravimetric & $2540-\mathrm{B}$ & \\
\hline SV & $\mathrm{mg} \mathrm{L}^{-1}$ & gravimetric & $2540-\mathrm{E}$ & \\
\hline $\mathrm{O} \& \mathrm{G}$ & $\mathrm{mg} \mathrm{L}^{-1}$ & $\begin{array}{l}\text { gravimetric by } \\
\text { centrifuging }\end{array}$ & - & $\begin{array}{c}\text { SUEHARA et al. } \\
(2005)\end{array}$ \\
\hline Turbidity & UNT & nephelometric & 2130-B & \\
\hline Color & $\mathrm{UC}$ & spectrophotometric & 2120-C & \\
\hline $\mathrm{pH}$ & - & potentiometric & $4500-\mathrm{H}^{+}-\mathrm{B}$ & \\
\hline NTK & $\mathrm{mgN} \mathrm{L}^{-1}$ & Semi-micro-Kjeldahl & $4500-\mathrm{N}_{\text {org }}-\mathrm{B}$ & \\
\hline Free acids & $\%$ & titrimetric & - & ROSA (2004) \\
\hline
\end{tabular}

The microorganisms were isolated in Petri plates previously prepared and sterilized, containing culture medium composed of $\left(\mathrm{g} \mathrm{L}^{-1}\right)$ : ammonium sulphate 1.0 ; yeast extract 1.0; potassium phosphate diacid 0.2 ; sulfate magnesium sulfate heptahydrate 0.2 ; and soybean oil 1.0. Through the streak-plate technique of the wastewater was inoculated on the plates, which were incubated for 24 hours at $30{ }^{\circ} \mathrm{C}$ for growth of microorganisms (SUEHARA et al., 2005). This procedure was repeated until each colony was found totally isolated from each plate.

Each microorganism isolated was tested regarding the potential of biodegradation of the waste under study, by determining the enzyme (lipase). To this end, a handle of the inoculum was inoculated isolated in Petri plates containing $\left(\mathrm{g} \mathrm{L}^{-1}\right)$ : peptone 10.0; sodium chloride 5.0; calcium chloride dihydrate 0.1 ; and agar 18.0. The plates were incubated at $30{ }^{\circ} \mathrm{C}$ for 96 hours and the Enzyme Index (EI) was determined after this time. The EI expresses the relationship between the diameter of the degradation halo of the substrate by the diameter of the growth of the microorganism colony (VIEIRA et al., 2006).

In order to define which microorganism, previously selected, had higher efficiency in the fat removing from the effluent under study, and find their respective times of maximum degradation, it was carried out a degradation test with the two strains with higher enzyme activity previously selected.

For this purpose, standardization of the inoculum was performed by optical density, adjusting the absorbance of the inoculum in a spectrophotometer at $580 \mathrm{~nm}$ wavelength, adding the cell suspension, at a dilution $10^{-1}$, until reaching the absorbance of 0.2 . This absorbance corresponded to $3.6 \times 10^{8}$ cells. $\mathrm{mL}^{-1}$ for the two microorganisms, measured by cell count after the construction of a dilution curve. The substrate used was prepared with $50 \mathrm{~mL}$ of biodiesel washing water, added a nitrogen source $\left(3 \mathrm{~g} \mathrm{~L}^{-1}\left(\mathrm{NH}_{4}\right)_{2} \mathrm{SO}_{4}\right)$. The amount of microorganism seeded on the agar plate should be standardized across all samples to be tested to enable comparison of results (TORTORA et al., 2006).

The biodegradation test was conducted under the conditions of $35^{\circ} \mathrm{C}$ and $180 \mathrm{rpm}$ rotation , having the microorganisms preselected (A and $\mathrm{B}$ ) and the time $(24 ; 48 ; 72 ; 96$ and $120 \mathrm{~h}$ ) as variables, with three replications for each sample. After cultivation, the substrate was spun at $2000 \mathrm{rpm}$ for 15 minutes, the precipitate was discarded and in the supernatant was analyzed the content of O\&G (SUEHARA et al., 2005) and the lipase activity (VIEIRA et al., 2006).

The previously selected microorganisms, used in the initial test of degradation of lipids, were identified as to their morphology and Gram staining. After defining the microorganism with higher efficiency of fat removal, they were sent to the Institute André Tosello (in Campinas, state of São Paulo, Brazil), in order to identify genus and species, by means of biochemical methods.

The evaluation of the results was performed by analysis of variance (ANOVA parametric) supported by the software Statistica 7.0®. Differences between means were evaluated by Tukey's test $a$ posteriori. For all analyzes it was adopted a significance level of 5\% ( $p<0.05)$. 


\section{RESULTS}

\section{Characterization of the residue}

The obtained values in the characterization of the residue are shown in Table 2. Only the $\mathrm{pH}$ shows value within the parameters established by CONAMA Resolution 430/2011, for effluent release. The other parameters show high values, requiring treatment for their subsequent release into water bodies.

TABLE 2. Characterization of biodiesel wastewater purification.

\begin{tabular}{lcccc}
\hline \multicolumn{1}{c}{ Parameters } & Unity & Mean value & Standard deviation & $\begin{array}{c}\text { Variation coefficient } \\
(\%)\end{array}$ \\
\hline ST & $\mathrm{g} \mathrm{L}^{-1}$ & 23.89 & 3.01 & 12.60 \\
SV & $\mathrm{g} \mathrm{L}^{-1}$ & 18.48 & 2.65 & 14.34 \\
O\&G & $\mathrm{g} \mathrm{L}^{-1}$ & 6.76 & 0.32 & 4.73 \\
TURBIDITY & $\mathrm{UNT}$ & 290 & - & - \\
COLOR & $\mathrm{UC}$ & 5.450 & - & - \\
pH & - & 6.2 & 0.10 & 1.61 \\
NTK & $\mathrm{mg} \mathrm{L}^{-1}$ & 0 & 0.00 & 0.00 \\
Free acids & $\%$ & 17.21 & 0.25 & 1.45 \\
\hline
\end{tabular}

According to DRANKA et al. (2008), the pH found in their study of wastewater of biodiesel purification was 6.3, similar to that presented in this study of 6.2. In the levels of oil and grease (O\&G) it was obtained a value of $2678 \pm 10 \mathrm{mg} \mathrm{L}^{-1}$, value lower than that found in the residue of this research, underlining the need for treatment with the adoption of a tightening of discharge standards of residual water. About the amount of nitrogen present in the washing water from biodiesel was null, demonstrating the need for the addition of this nutrient in possible biological treatments.

To control such situation, the National Council of Environment (CONAMA), by resolution 430 of May 13, 2011, settled conditions for release effluents into water bodies: $\mathrm{pH}$ from 5.0 to 9.0; temperature less than $40{ }^{\circ} \mathrm{C}$; concentration of mineral oil up to $20 \mathrm{mg} \mathrm{L}^{-1}$, and for vegetable oils and animal fats up to $50 \mathrm{mg} \mathrm{L}^{-1}$ (CONAMA, 2011).

\section{Microorganisms selection}

Based on the diameters of halos and colonies found in the test of the activity of lipase production, it was determined the enzymatic index - EI (Table 3). The lower the EI, the greater the potential presented by the microorganism for enzymatic production; if the EI is equal to 1.0 means that the enzyme production is null; if it is between 1 and 0.64 the production is positive; and if it is less than 0.64 indicates the microorganism has a production strongly positive (RIBAS et al., 2009).

TABLE 3. Average enzymatic index (EI) found for each microorganism, based on the relationship between colony diameter and colony diameter + halo.

\begin{tabular}{cccc}
\hline Microorganism & Colony Diameter $(\mathrm{cm})$ & $\begin{array}{c}\text { Colony Diameter } \\
+ \text { Halo }(\mathrm{cm})\end{array}$ & EI \\
\hline A & 2.67 & 4.37 & 0.56 \\
B & 2.20 & 3.77 & 0.57 \\
C & 3.17 & 4.53 & 0.69 \\
D & 3.90 & 5.00 & 0.74 \\
E & 3.07 & 4.13 & 0.74 \\
F & 1.33 & 1.33 & 1.00 \\
\hline
\end{tabular}

Thus, it can be observed that, the isolated strain "F" showed no production of lipase and the "A" has the highest enzyme activity, but most strains with a positive production (Figure 1). 


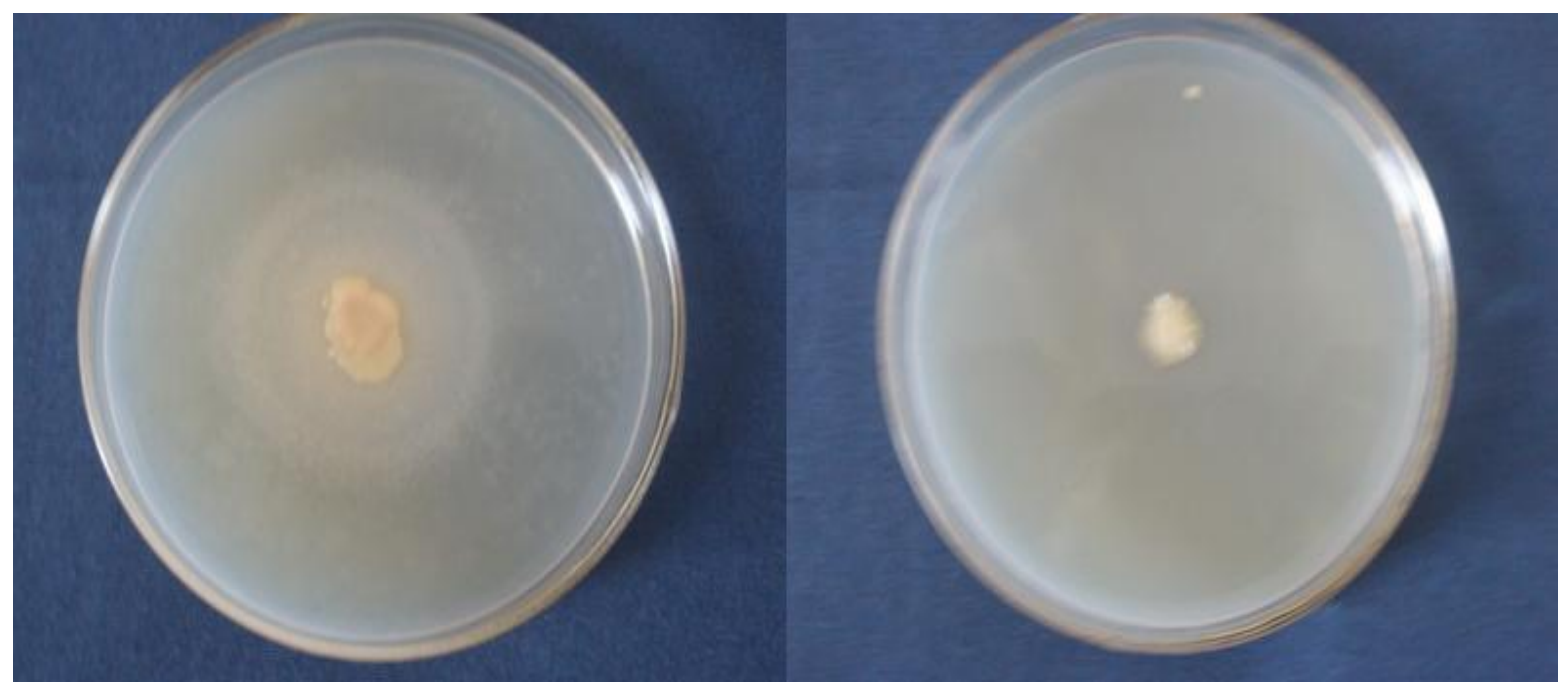

FIGURE 1. Pictures of the isolated strains; on the left (microorganism B) with degradation halo; on the right (microorganism F) without degradation halo.

Based on statistical analysis carried out, the significance of the variable in the microorganism producing the enzyme may be confirmed. The microorganisms identified with $\mathrm{A}$ and $\mathrm{B}$ were statistically similar, at 5\% significance level, and the lowest EI, that is, the highest potential for fat degradation (Figure 2).

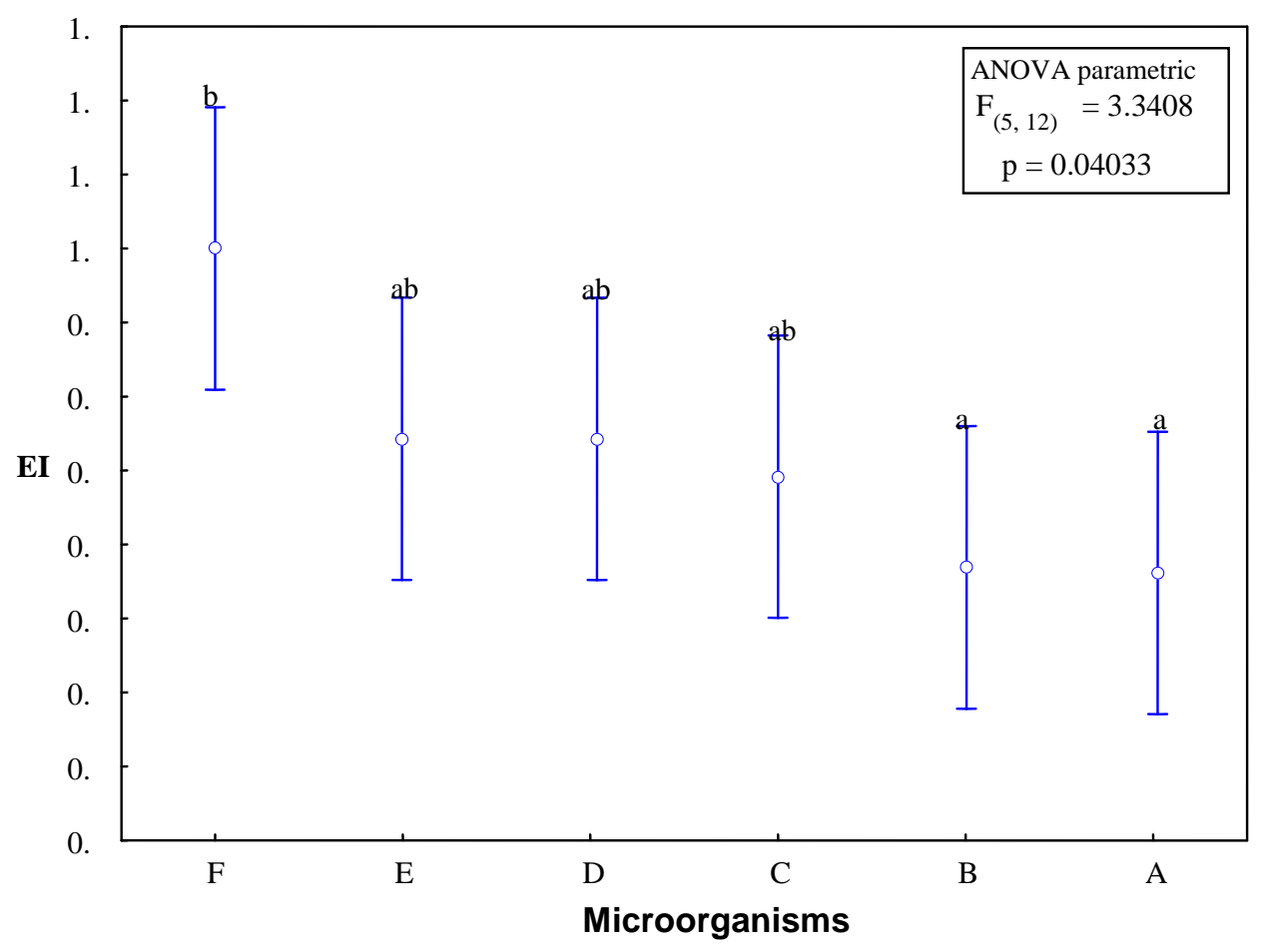

* Different letters indicate significant differences $(\mathrm{p}<0.05)$ by Tukey's test $a$ posteriori.

FIGURE 2. Mean $\pm 95 \%$ EI for enzymatic index values obtained by different microorganisms.

LOPERENA et al. (2009), when isolating microorganisms natives of aerobic treatment of wastewater from dairy products, 41 cultures were obtained, from which 19 have produced lipase, 12 protease and two cultures have produced both enzymes, and 21 had high potential of lipolytic activity and / or proteolytic activity.

DARTORA et al. (2003) in order to select microorganisms that produce extracellular enzymes of the type lipases have isolated microorganisms using liquid culture medium based on cheese whey 
under conditions of $30^{\circ} \mathrm{C}$ for 48 hours. As a result, from 12 isolated strains (seven yeast strains, two filamentous fungi and three bacteria), demonstrated lipolytic activity through enzymatic index (EI) in three yeast strains, two strains of bacteria and two filamentous fungi are producers of lipases.

VIEIRA et al. (2006), studying the ability of degradation of biodiesel from palm oil by bacteria previously isolated from diesel storage tanks, with capacity of degrading diesel, ascertained that 16 out of 25 bacterial isolates, or $64 \%$, had at least one enzyme activity (lipase and/or esterase). Moreover, they concluded that the test of enzyme activity using Tween 20 and Tween 80 proved to be effective for the selection of bacteria with the capacity of using biodiesel, because in the degradation tests of biodiesel, the selected bacteria were able to use this product.

\section{Test of degradation of lipids}

Considering that the content of oil and grease $(\mathrm{O} \& \mathrm{G})$ as a variable of response, and the type of inoculums used and the incubation period as predictors in the ANOVA test, it can be verified that only the variable "time" has been statistically significant at 5\% probability (Table 4).

TABLE 4. Analysis of variance (ANOVA) for O\&G content.

\begin{tabular}{lcccrc}
\hline & Sum of the Squares & Liberty level & Sum of Means & F & P \\
\hline Time & 101.67 & 5 & 20.33 & 14.97 & 0.000 \\
Inoculums & 4.68 & 1 & 4.68 & 3.44 & 0.076 \\
Time*Inoculums & 11.50 & 5 & 2.30 & 1.69 & 0.175 \\
Error & 32.59 & 24 & 1.36 & & \\
\hline
\end{tabular}

Based on the curve of reducing the content of $O \& G$, throughout the 120 hours of incubation for two selected microorganisms (Figure 3), it can be observed that despite not differ statistically, the microorganism A showed a removal of fat higher than the microorganism B. At time of 120 hours, the microorganism "A" provided a removal of $87 \%$ of the fat of the effluent under the conditions, producing a lipase activity of $0.30 \mathrm{U} \mathrm{mL}^{-1} \mathrm{~min}^{-1}$, compared to $79 \%$ of removal of fat and lipase activity of $0.29 \mathrm{U} \mathrm{mL}^{-1} \mathrm{~min}^{-1}$ produced by microorganism "B". The variable "time", as from 24 hours of incubation, variation was not made in the removal of fat in the Tukey test (0.05), at the time of $48 \mathrm{~h}$ the microorganism removed $80 \%$ of the $\mathrm{O} \& \mathrm{G}$ of effluents.

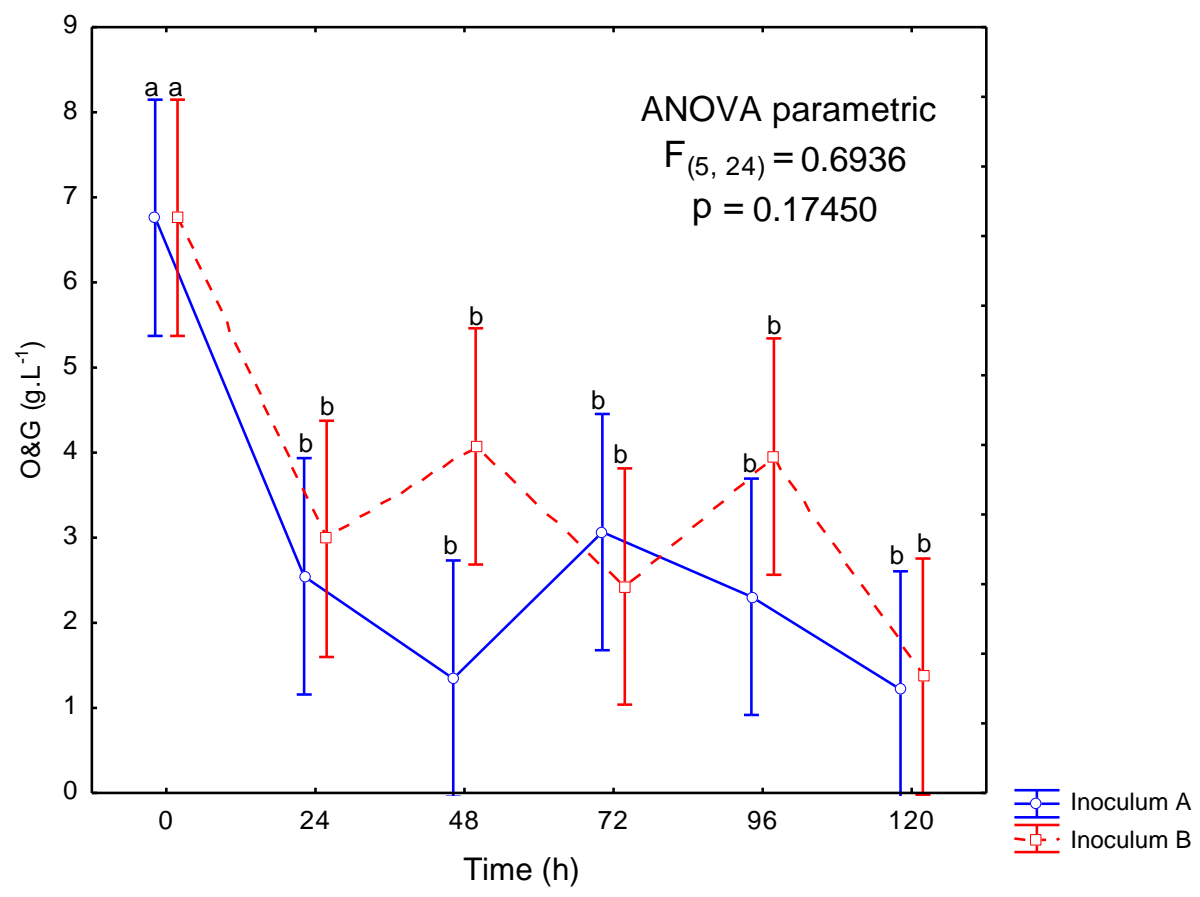

* Different letters indicate significant differences $(\mathrm{p}<0.05)$ by Tukey's test a posteriori.

FIGURE 3. Assay of reducing of O\&G content. 
DURLI (2007), in order to reduce the amount of fat contained in the effluent, used lipases of Burkholderia cepacia LTEB11, and the removal of O\&G predicted by the model was $60 \%$, after 48 hours, under a condition from 29 to $32^{\circ} \mathrm{C}, \mathrm{pH}$ from 8.0 to 9.2.

RAJENDRAN \& THANGAVELU (2009) evaluated the lipase production by Rhizopus arrhizus, in a mixture of components, and found a maximum value of lipase production equal to $3.98 \mathrm{U} \mathrm{mL}^{-1}$. BROZZOLI et al. (2009) have produced lipase using wastewater of the industry producer of olive oil as the culture medium for Candida cylindracea and obtained values that reached $20.4 \mathrm{U} \mathrm{mL}^{-1}$. These values are much greater than the lipase production obtained in this experiment, possibly, due to the characteristics of the waste that have not favored microbial growth.

\section{Microorganism Identification}

Morphological analysis showed that two strains with high potential for microbial production of lipase, known as A and B, are bacteria which have the form of bacilli with coloring negative Gram (Figure 4).

The strain called "A", which presented the best results for removal of fat of the wastewater from biodiesel washing, under the conditions studied it was identified as Klebsiella oxytoca (Flugge 1886) Lautrop 1956 (Figure 4). This is a microorganism that is found in the intestinal tract of living beings and animal, and it may be isolated from various pathological processes and from the aquatic and botanical environments.

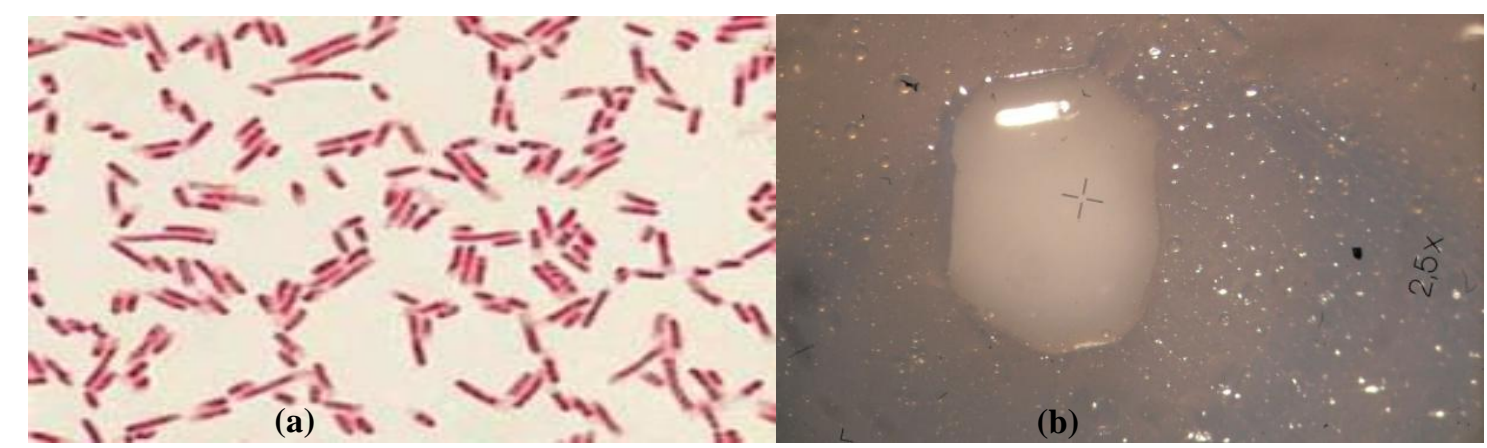

FIGURE 4. (a) Illustrative picture of Gram negative bacilli. (b) Photograph of the isolated colony of Klebsiella oxytoca (Flugge 1886) Lautrop 1956.

\section{CONCLUSIONS}

However, it is concluded that the biodiesel wastewater purification, has a high potential of environmental impact and needs an efficient treatment to fit the standards of releases required by CONAMA 430/11, the concentration of oil and grease $(\mathrm{O} \& \mathrm{G})$ with a concentration of $6.76 \mathrm{~g} \mathrm{~L}^{-1}$ is highlighted.

From the six microbial cultures isolated from the settling tank, where the collect from this effluent took place, two microorganisms were selected presenting high potential for production of lipase, with enzymatic index of 0.56 and 0.57 . These microorganisms are, therefore, indicated for further study with the aim of being used in the pretreatment of removal of fat from wastewater of biodiesel purification, once they have adapted to the residue with such specific characteristics. We highlight that the isolated strain Klebsiella oxytoca the one that achieved better treatment outcomes.

\section{REFERENCES}

ALESSI, M.C.M. Avaliação da hidrólise alcalina da gordura sobre a biodegradação anaeróbia de soro de queijo. 2005. 83 f. Dissertação (Mestrado) - Universidade Federal de Uberlândia, Uberlândia, 2005. 
APHA; AWWA; WEF. Standard methods for the examination of water and wastewater. $21^{\text {st }}$ ed. Washington, 2005. $1268 \mathrm{p}$.

BROZZOLI, V.; CROGNALE, S.; SAMPEDRO, I.; FEDERICI, F.; D’ANNIBALE, A.; PETRUCCIOLI, M. Assessment of olive-mill wastewater as a growth medium for lipase production by Candida cylindracea in bech-top reactor. Bioresource Technology, Fayetteville, v.100, p.33953402, 2009.

CASTRO, H.F.; ANDERSON, W.A. Fine chemicals by biotransformation using lipases. Química Nova, São Paulo, v.18, p.544-554, 1995.

CONAMA. CONSELHO NACIONAL DE MEIO AMBIENTE. Legislação Ambiental Federal, Resolução n 430, 2011. Disponível em:

<http://www.mma.gov.br/port/conama/legiabre.cfm?codlegi=646>. Acesso em: 02 jul. 2012.

DARTORA, D.F.; HENDGES, D.H.; SANGALETTI, N.; OLDONI, T.L.C.; ALENCAR, S.M.; ONOFRE, S.B. Isolamento e seleção de microrganismos produtores de lipases a partir do soro de queijo. In: SIMPÓSIO NACIONAL DE FERMENTAÇÕ̃ES, 2003, Florianópolis. Anais... p.T165.

DRANKA, G.G.; FAUSTO, G.L.; RODRIGUES, M.B. Avaliação do potencial impactante da água residuária do processo de produção do biodiesel. In: ENCONTRO DE QUÍMICA DA REGIÃO SUL, 16., 2008, Blumenau. Anais...

DURLI, E. Tratamento de efluente de indústria de laticínios utilizando lipases de Burkholderia cepacia LTEB11. 2007. 111 f. Dissertação (Mestrado) - Universidade Federal do Paraná, Curitiba, 2007.

GERIS, R.; SANTOS, N.A.C.; AMARAL, B.A.; MAIA, I.S.; CASTRO, V.D.; CARVALHO, J.R.M. Biodiesel de soja - reação de transesterificação para aulas práticas de química orgânica. Química Nova, São Paulo, v.30, n.5, p.1369-1373, 2007.

LOPERENA, L.; FERRARI, D.; DÍAZ, A. L.; INGOLD, G.; PÉREZ, L. V.; CARVALLO, F.; TRAVERS, D.; MENS, R. J.; LAREO, C. Isolation and selection of native microorganisms for the aerobic treatment of simulated dairy wastewaters. Bioresource Technology, Kidlington, v.100, p.17621766, 2009.

MENDES, A.A.; CASTRO, H.F.; PEREIRA, E.B.; FURGIO JR. A. Aplicação de lipase no tratamento de águas residuárias com elevado teor de lipídeos. Química Nova, São Paulo, v.28, n.2, p.296-305, 2005.

RAJENDRAN, A.; THANGAVELU, V. Statistical experimental design for evaluation of medium components for lipase production by Rhizopuz arrhizus. LWT - Food Science and Technology, Zürich, v.42, p.985-992, 2009.

RAMOS, L.P.; DOMINGOS, A.K.; KUCEK, K.T.; WILHELM, H.M. Biodiesel: um projeto de sustentabilidade econômica e sócio-ambiental para o Brasil. Biotecnologia: Ciência e Desenvolvimento, Brasília, v.31, p.28-37, 2003.

RIBAS, T.T.Z.; MARCHESAN, E.D.; ONOFRE, S.B. Atividade hemolítica de Streptomyces sp. Produtores de metabólicos ativos, isolados do solo da região sudoeste do Paraná. Revista de Biologia e Saúde da UNISEP, Dois Vizinhos, n.1, p.27-33, jan./jun. 2009.

SUEHARA, K.; KAWKMOTO, Y.; FUJII, E.; KOHDA, J.; NAKANO, Y.; YANO, T. Biological treatment of wastewater discharged from biodiesel fuel production plant with alkali-catalyzed transesterification. Journal of Bioscience and Bioengineering, Osaka, v.100, n.4, p.437-442, 2005.

TORTORA, G. J.; FUNKE, B. R.; CASE, A. L. Microbiologia. 8.ed., Porto Alegre: Artmed, 2006, $894 \mathrm{p}$. 
VALLADÃO, A.B.G.; FREIRE, D.M.G.; CAMMAROTA, M.C. Enzymatic prehydrolysis applied to the anaerobic treatment of effluents from poultry slaughterhouses. International Biodeterioration \& Biodegradation, Barking, v.60, p.219-225, 2007.

VIEIRA, T. M.; SILVA, E. P.; FILHO, N. R. A.; VIEIRA, J. D. G. Determinação e quantificação da degradação bacteriana de biodiesel de óleo de palma. In: CONGRESSO DA REDE

BRASILEIRA DE TECNOLOGIA DE BIODIESEL, 2006, Brasília. Anais... p.218-223. 